\title{
A Systematic Review and Trend Analysis of Personal Learning Environments Research
}

\author{
Sarah A. L. Serhan and Noraffandy Yahaya
}

\begin{abstract}
The concept of personal learning environments (PLEs) is relatively new and is continuously developing. Over the past decade, there has been a significant upsurge in the number of PLEs-related research. Nevertheless, there is a lack of recent systematic reviews and trend analysis covering many PLEs studies; to the best of our knowledge. Therefore, the current systematic review is significant and indispensable in reviewing journal articles that discussed PLEs between 2000 and 2020. We searched Web of Science, Scopus, Sciences Direct, JSTOR, Springer, Google Scholar, and IEEE Xplore for studies published in English without limit in location or time to retrieve accurate results. Trend graphics for the extracted themes were also analyzed using descriptive statistics in Excel. According to the defined inclusion criteria, one hundred forty-eight articles were selected for the analysis. This study reveals that literature on PLEs has progressed from 2000 to 2020 ; the majority of PLEs-related articles were published between 2011 and 2020, with the year 2013 having the highest number of published articles (17 articles), followed by 16 papers published in both years 2014 and 2017. We found that the published PLEs research originated from 46 countries; $26(17.6 \%)$ were from Spain. The majority of the authors had education, computer science, information technology and engineering backgrounds. This review also showed that numerous platforms had been used in PLEs research, with Web 2.0 the most commonly used platform. We noted that the most common objectives of the included articles were PLEs custom system development, analysis of the PLEs, description of experiments, investigations, development of factor models, framework development, and examination. The most common theoretical perspectives in the published articles were self-regulated learning, self-directed learning, and constructivism. The current systematic review and trend analysis can become a guidance platform for researchers, educators, policymakers or even journal publishers for future research in PLEs research.
\end{abstract}

Index Terms-Personal learning, personal learning environment, systematic review, trend analysis.

\section{INTRODUCTION}

Personal learning (PL) is identified as lifelong learning, which deals with getting information differently [1]. According to Schwartz (2016), learners should be provided with the flexibility to enhance their various skills to analyze data critically [2]. In this manner, the notion of Personal Learning Environments (PLEs) was initially studied by Olivier and Liber [3]. They addressed the PLEs as a crucial resource for e-learning and Interactive Learning Environments (ILE).

Manuscript received July 9, 2021; revised August 6, 2021.

The authors are with the Universiti Teknologi Malaysia, Skudai, Johor, Malaysia (corresponding author: Sara.h A. L. Serhan; e-mail: sarah.alsarhan@hotmail.com, p-afandy@utm.my).
In the same vein, Kulathuramaiyer and Maurer (2007) portrayed PLEs as a great assistance to information management and the cognitive load that accompanies it [4]. PLEs have been cited as a reliable user interface to meet the needs of lifelong learners to manage their educational careers [3]. According to Taraghi and Ebner (2011) and Alalwan et al. (2019), in an environment where learners can integrate the distributed resources, applications and tools in a single platform can be tailored to individual learners to offer an acceptable circumstance for developing their specific needs in a study environment that allows people to interact within collaborative and distributed environments [5], [6]. In this situation, PLEs are an instructive approach that enables students to employ social media to enhance self-regulated learning in both official and non-official pedagogical contexts [7], [8].

Many researchers conducted different studies and found that the PLE notion has implications on open-access online learning and learner-based guidance, self-direction, and self-regulation [9], [10]. Counted as the significant point of PLEs research, Buchem et al. (2012) believe that creating customized platforms would not be the purpose of the study by focusing on obtaining the learners' activity in terms of their employment of technology for supporting their learning process [11]. Also, Van Harmelen (2006) considers that PLEs play a significant role as a system that assists learners in managing and controlling learning by setting their targets and communicating with other learners to fulfil their objectives [12]. This explanation in the perspective of Panagiotidis (2014) is identified as a particular designed system that covers many external tools and resources for developing a customized learning experience that can be accessed individually [13], which is in line with the perspective of several researchers who believe that PLEs enables learners to engage their peers, resources as well as services in a broad context [14]. Apart from the significant role of the PLEs in learning and engaging learners, the PLEs have been challenging the traditional Learning Management System (LMS).

According to Ullrich et al. (2010), LMS should be recognized as a suitable solution for institutions [14]. In this sense, PLEs should ideally aim to enhance the learners' cognitive abilities, redefine the pedagogical process, and integrate third-generation LMS to design technology-enhanced practices and opportunities [15], [16]. Therefore, Hicks and Sinkinson (2014) and Patricia Ibañez et al. (2019) believe that it is crucial to enhance PLEs, mainly because digital information is being developed [17], [18]. Thus, learners will establish their own self-reflective and learning environments and create and manage their learning environments through the required tools [19], [20]. 
According to Schwartz (2016) and Al-Rahmi et al. (2019), since the components such as learning progress, technology and resources are provided to help all learners, the outcome would be even more attractive to the students and prompt greater responsibility and improve the results [2], [21]. Therefore, over the course of the previous century, educational professionals and researchers have addressed several theories to identify how learners need, organize and employ skills and knowledge. Under this circumstance, various approaches have been organized for helping learners and educators as well as researchers.

There is a lack of recent systematic reviews and trend analysis covering many PLEs studies to the best of our knowledge. Therefore, the current systematic review is significant and indispensable in reviewing journal articles that discussed PLEs between 2000 and 2020. The present systematic review and trend analysis can become a guidance platform for researchers, educators, policymakers or even journal publishers for future research in PLEs research.

Consequently, the current systematic review is crucial to review journal articles that discussed PLEs to investigate the following research questions in particular:

1) What is the year of publication, the country of origin of published articles on the PLEs, the author background between 2000 and 2020 ?

2) What are the objectives and research methodology of these published articles?

3) What are the most common PLEs platforms that were mentioned in these published articles between 2000 and 2020 ?

4) What is the theoretical perspective on personal learning environments mentioned in these published articles between 2000 and 2020 ?

\section{Methodology}

It should be considered that systematic literature is a fundamental scientific activity that enables scientists to consider authors' perspectives in a specific area. A systematic literature review synthesizes, evaluates, and identifies research results for creating a summary of evidence that can effectively contribute to practice. In general, systematic review methodology makes use of principles that are needed in primary research. Typically, this review addresses above mentioned specific research questions with evidence from the studies.

A systematic literature review has been considered in this research because it offers several benefits. First of all, they serve to deliver a comprehensive and clear overview of the available evidence on a specific topic [22]. In addition, these reviews help identify research gaps in the current understanding of the topic and field. They are capable of highlighting methodological concerns in studies that can be further utilized for improving work. They can also be considered for identifying questions for which the evidence seems to provide clear answers. It is important to note that a systematic literature review was performed to identify journal articles that discussed PLEs between 2000 and 2020.

\section{A. Data Sources and Search Strategy}

We searched Web of Science, Scopus, Sciences Direct, JSTOR, Springer, Google Scholar, and IEEE Xplore for studies published in English without limit in location or time to retrieve accurate results. According to the research questions mentioned earlier, we used a combination of search terms, including 'Personal Learning Environments' OR 'Personal Learning Environment' OR 'Personalized Learning Environment'.

\section{B. Eligibility Criteria}

The inclusion criteria were 1) Studies published in most influential journals, 2) Studies must be peer-reviewed in a journal. The following are the exclusion criteria of this systematic review: 1) a language other than English, 2) citations without full text, 3) Published articles in symposium and conference proceedings OR workshop OR editorials OR commentaries OR are mentioned in a technical report OR MS/Ph.D. thesis.

\section{Quality Assessment of the Included Articles}

We evaluated the methodological quality of the included articles by the Newcastle-Ottawa Scale for grading the quality of observational studies [23]. The quality rating was out of 9 , scores between 0 and 3 referring to a low rate, scores between 4 and 6 medium quality, scores between 7 and 10 high quality. The evaluations of all articles were compared between the evaluators, with discrepancies resolved unanimously.

\section{Study Screening and Data Extraction}

To guarantee sufficient data to monitor research trends, the publication period was set as a decade from 2000 to 2020 . The type of publication was selected as "peer-reviewed articles".

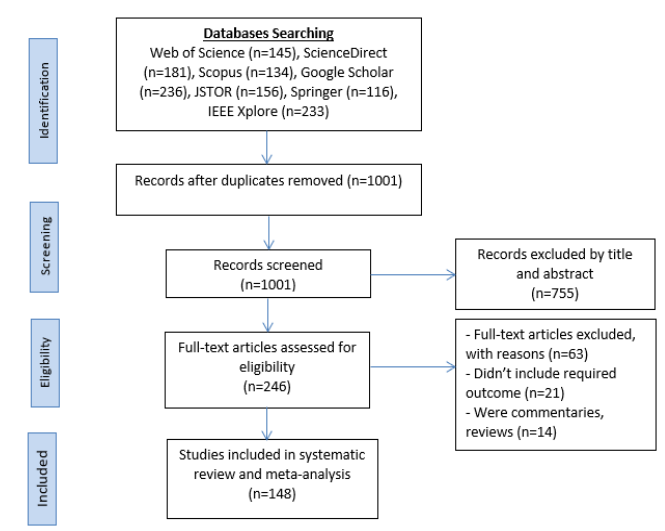

Fig. 1. The PRISMA flowchart presenting the search strategy for the current systemic review.

The resulted articles from the literature search (1201 articles) were imported to EndNote X8 software to eliminate duplicates and manage the screening processes. The remained articles after removing duplications were (1001 articles). Then, 755 articles were excluded by title and abstract screening. Eventually, the authors did the full-text screening and reviewing, working independently and duplicating to decide their eligibility for full-text reviewing. One hundred forty-eight articles were eligible to be included in the systematic review.

Fig. 1 illustrates the PRISMA flowchart to show the search 
strategy for the systematic approach for collection, processing, and reviewing the articles [24].

The critical information extracted from the articles included 1) country of the first author, 2) year of publication, 3) category of study objective, 4) study design, 5) the used platforms, 6) theoretical perspectives, 7) the employed data collection instrument, 8) study population, 9) author background.

\section{E. Data Analysis}

Trend graphics for the extracted themes were analyzed using descriptive statistics in Excel.

\section{RESULTS AND DISCUSSION}

We have collected more than 148 articles related to PLS. As PLS is becoming an issue among educators, we can see an increase in the number of articles available per year from 2000 until 2020.

The inclusion of many articles related to PLEs could be attributed to the multi-disciplinarity of the PLEs notion. It has been used in education, information technologies, computer science, engineering, economics, information management, business, biotechnology, health and life sciences, communication, informatics, telecommunication, medicine and health, artificial intelligence, etc.

In practice, the implementing of PLEs in various educational levels and fields is entirely under investigation [25]-[29]. PLEs is an expanding field, especially in academic research, as evidenced by the increasing number of research papers published in the last ten years and the launch of the PLE Conference, known as PLEConf (pleconf.org).

Advocates of PLEs propose that through effective building and use of PLE, learners will regain control of their learning process through the ability to select and mix from several alternatives (among other actions) to capture, store, classify, analyze, create, share, disseminate and process information, hence generating knowledge [26], [30]-[32].

\section{A. The Publishing Year of PLEs-Related Articles}

Our analysis showed that most PLEs-related articles were published between 2011 and 2020.The year 2013 had the highest number of the published articles (17 articles), followed by 2014 and 2017 as 16 papers were published in these two years (Fig. 2).

The first appearance of the PLEs acronym was in November 2004 as a title of a session in the 2004 JISC / CETIS conference [33]. In 2001, the NIMLE (Integrated Managed Learning Environment for Northern Ireland) was established; accordingly, Brown (2010) selected the start date for the PLEs approach. Taraghi, Ebner, and Schaffert (2009) [32] referred to Olivier and Lieber (2001) among the earliest to express the idea of PLEs [3].

We can consider PLE as a concept in fashion when numerous exceptional editions were launched from recognized publications in 2008: E-Learning Articles [34] or Interactive Learning Environments [35].

The notion of the personal learning environment has a long history. Based on Google Ngrams (http://ngrams.googlelabs.com/), the term personal learning environment was first quoted in 1965. We noticed that a 1969 publication of the University of Washington emphasized that each student's interests and aspirations seem to be a precondition for building their learning environment.

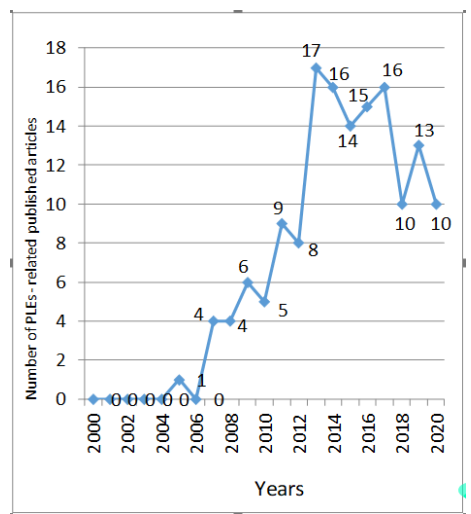

Fig. 2. Distribution of the published articles according to the publication year.

Until the previous year, in 1968, the Association for Student Education also referred to the term PLE, which could be drawn up by a qualified associate to share experiences in a learning environment.

Consequently, we can guess that the personal environment for learning originates from thoughts regarding the individualization and personalization of education in the late sixties. Nevertheless, the technological attitude is first seen in the twenty-first century. If we recognize that around that moment, the web and computer technologies have been presented for more than 10 and 20 years, respectively, why hasn't PLE appeared before?

\section{B. First Author Country}

We have extracted that researchers from forty-six countries published articles between 2000 and 2020. The most published articles, twenty-six, are from Spain. The second and third most published papers are from the USA, fifteen, and the UK, twelve (Fig. 3). We can also infer that literature on personal learning environments (PLEs) is spread across continents. Researchers are rigorously working on this emerging field to make the most out of it. The other countries are Germany, Finland, Thailand, Malaysia, India, Pakistan, Brazil, etc.

\section{First Author Background}

Most of the authors had education, computer science, information technology and engineering background. The rest came from various backgrounds such as communications, telematics, informatics and many more (Fig. 4).

\section{RESEARCH OBJECTIVES}

A mind map was developed to visually organize information on the themes of personal learning environments, including articles, research design, and data collection (Fig. 5). We noted that the most common objectives of the included articles were PLEs custom system development, analysis of the PLEs, description of experiments, investigations, development of factor models, framework development, and examination. 


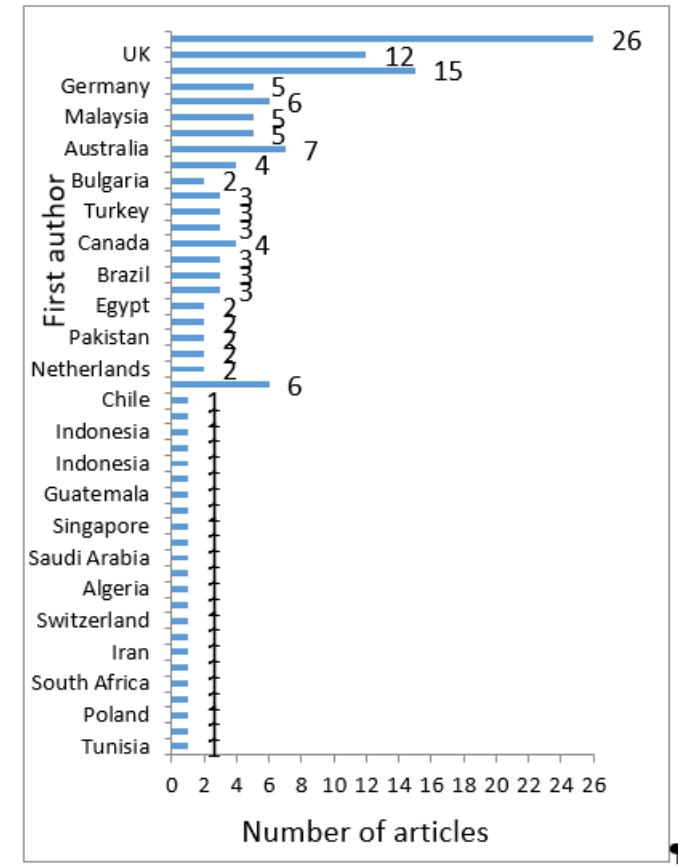

Fig. 3. Distribution of the published articles according to country of first authors.

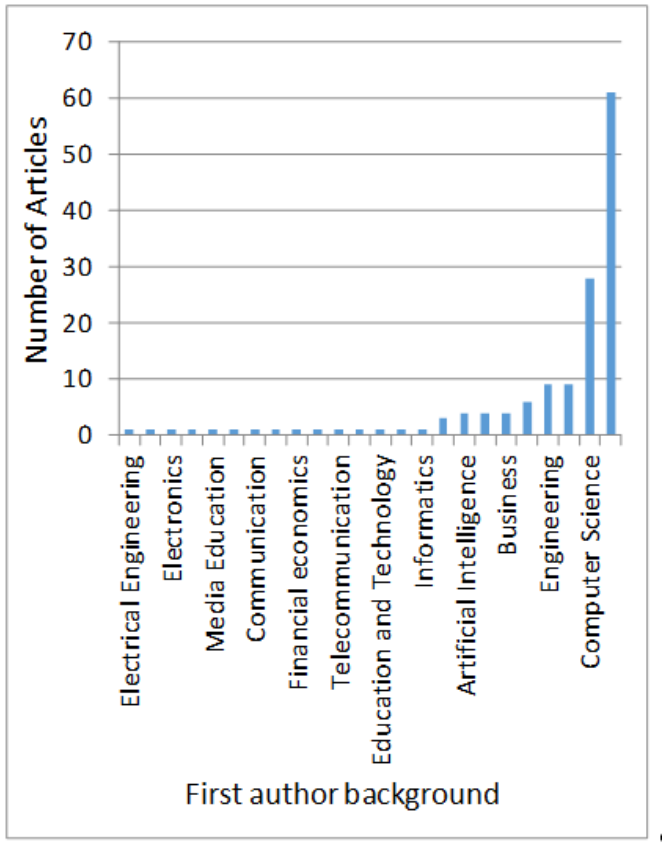

Fig. 4. Distribution of the published articles according to first author background.

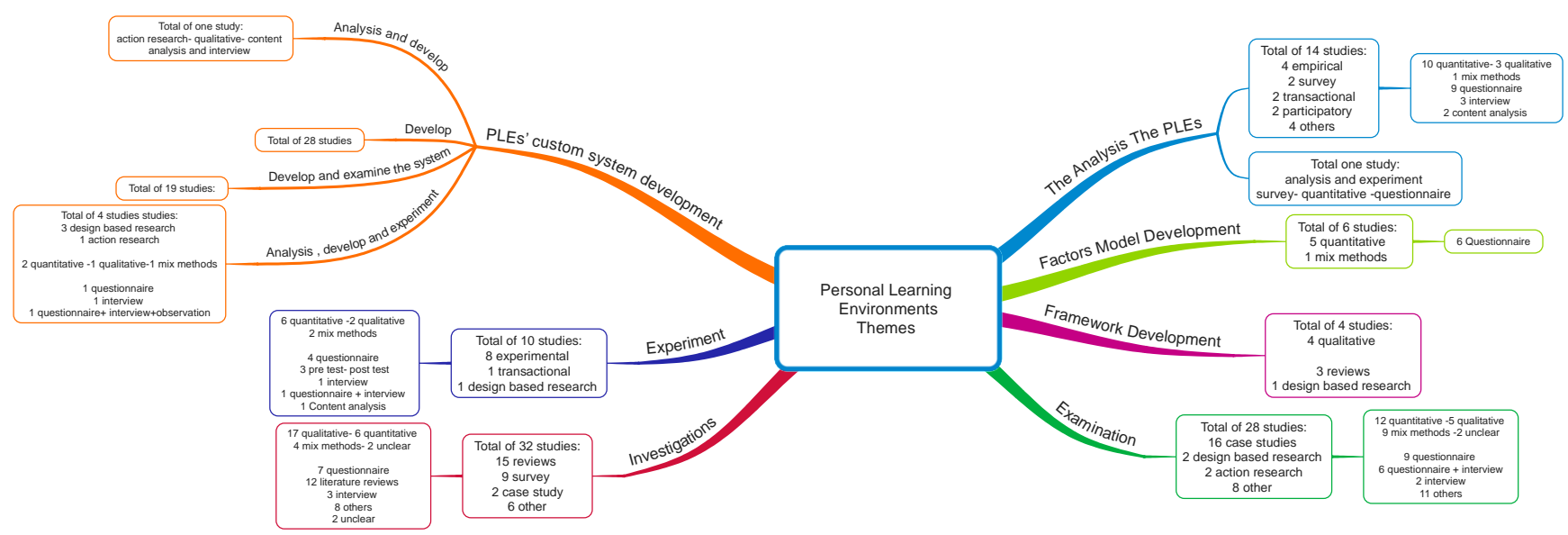

Fig. 5. A mind map to visually organize information about articles objectives, research design, and data collection instrument.

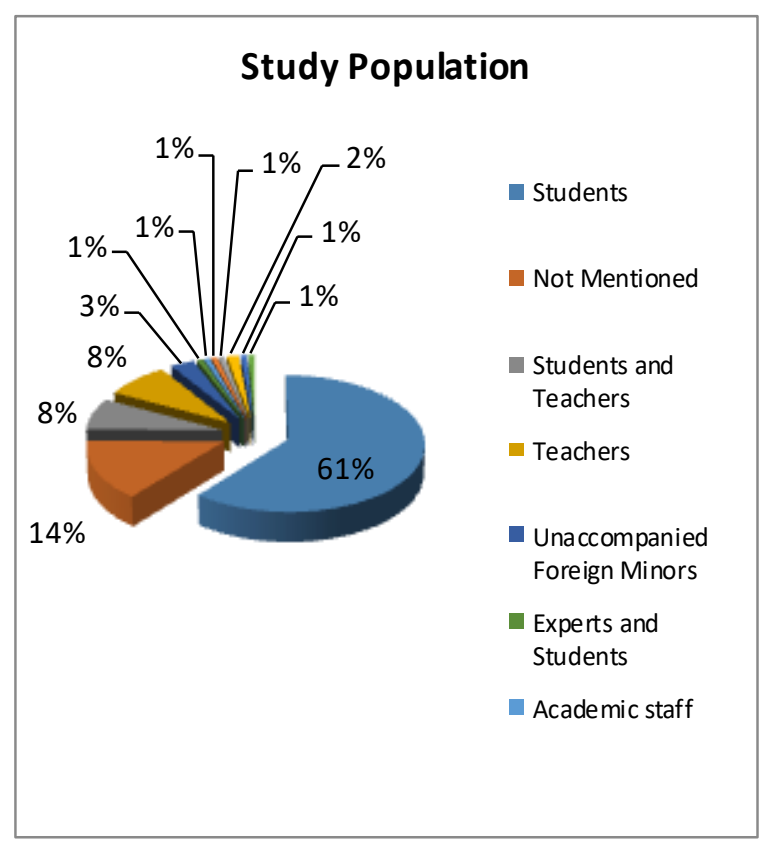

Fig. 6. Distribution of the published articles according to the studied population.
The four principal research methodologies used in published papers were system model development, case study, survey design, and review articles. These primary methodologies have helped develop and test the literature on PLEs.

Various data instruments were used for data collection in the included articles. The most employed tools were questionnaires, literature reviews, and interviews.

\section{StUdy POPULATION}

Fig. 6 shows that $81(61 \%)$ published articles on topics related to PLEs targeted academic staff, 11 (8\%) targeted students, $11(8 \%)$ targeted students and teachers together. Other population groups were also found.

\section{PLATFORMS}

This review showed that numerous platforms had been used in PLEs research. Web 2.0 was the most commonly used platform in PLEs research, as it has been used unilaterally in 
27 articles and with other social media platforms in 6 articles. The mash-up tools were used in 26 articles. The custom e-learning systems were used in 24 articles. LMS has been unilaterally used in 7 papers and 6 articles with Web 2.0 or other social media platforms (Table I).

TABLE I: THE USED PLATFORMS IN THE INCLUDED ARTICLES

\begin{tabular}{|c|c|c|c|}
\hline Platform & References & Platform & References \\
\hline Web 2.0 & [36]-[63] & $\begin{array}{l}\text { Open-access } \\
\text { services }\end{array}$ & {$[64]$} \\
\hline $\begin{array}{l}\text { Mash-up } \\
\text { tools }\end{array}$ & $\begin{array}{c}{[28],} \\
{[65]-[89]}\end{array}$ & $\begin{array}{l}\text { Open-Source } \\
\text { Software }\end{array}$ & [90] \\
\hline $\begin{array}{l}\quad \text { Custom } \\
\text { e-learning } \\
\text { systems }\end{array}$ & [91]-[115] & $\begin{array}{l}\text { Cloud-based } \\
\text { tools }\end{array}$ & [116] \\
\hline $\begin{array}{l}\text { Web } 2.0 \\
\text { and } \text { social } \\
\text { media }\end{array}$ & [117]-[123] & $\begin{array}{l}\text { Mobile } \\
\text { learning }\end{array}$ & {$[124]$} \\
\hline $\begin{array}{l}\text { Social } \\
\text { media }\end{array}$ & $\begin{array}{l}\text { [7], [35], [89], } \\
{[125]-[139]}\end{array}$ & SymbalooEDU & {$[140]$} \\
\hline Facebook & [141]-[143] & Mooc & [144] \\
\hline LMS & {$[145]-[148]$} & ICT & [149] \\
\hline Moodle & {$[150],[151]$} & Google apps & [152] \\
\hline $\begin{array}{l}\text { Tag-based } \\
\text { system }\end{array}$ & [153], [154] & WordPress & [155] \\
\hline ePortfolio & {$[33],[156]$} & Multimedia & {$[157]$} \\
\hline Blogs & {$[158]$} & Symbaloo & [159] \\
\hline $\begin{array}{c}\text { Open } \\
\text { Textbooks }\end{array}$ & [160] & e system & {$[161]$} \\
\hline
\end{tabular}

After reviewing the literature, we can describe the three LMS generations using many features, comprising interoperability, interaction, practice, and learning knowledge.

The first generation of PLEs includes proprietary solutions and concentrates on content dissemination. This generation is linked to the theory of computer-aided education systems. These learning systems are self-reliant and permit very little or no interaction between pupils and tutors.

The second generation of LMS relies on so-called classroom-based learning systems, which deliver central learning from content dispersed by lecturers. Such approaches support interaction between teachers and students and employ several technologies to provide learning actions. For instance, marketable platforms like Blackboard (www.blackboard.com), open-source systems such as Moodle (www.moodle.org), Sakai (www.sakaiproject.org), and dotLRN (www.dotlrn.org). Since IT systems are dynamic, all structures of these platforms enable extensions [142], [162], like Blackboard Building Blocks, WebCT Powerlink's, Sakai's Tech Portability Profile tools, and Moodle Modules. Nonetheless, these platforms are independent and cannot be reused in various environments. Notwithstanding their apparent contributions, they present a heuristic experience of the learning context [163] while remaining centralized and locked. Users cannot customize their learning environments, and a marked shift occurs from the learning environment to a daily learning environment.

Third-generation learning management systems are service-oriented, allowing users to easily create individual and reusable learning contexts [164]. They also use open Internet standards to support lightweight interoperability. Such characteristics make the 3rd generation of learning platforms user-centered. At this point, half of the third-generation LMS implementation is targeted PLEs. In these environments, the learning experience is enhanced by creating and using individual contexts. This allows for substantial methodological flexibility and could create a new model of virtual courses. These courses can be considered as a combination of LMS educational services and a range of external services. Most of the existing e-learning platforms belong to the 3rd generation, and some have gotten institutional acceptance [165].

Belonging to the 3rd generations of e-learning systems, PLEs have been proposed as a resolution to address the risks of VLEs by giving learners additional control and freedom in selecting and disseminating various tools and strategies to guide their learning and pursue their varied educational aims [28] (A designed framework for Personal Learning Environment). According to many researchers, PLEs help learners blend their personal and professional interests into one place and learn from each other's skills, experiences and knowledge [166], [167].

Besides, many researchers believe that the concept of PLEs has implications for open online learning, learner-based guidance, self-guidance issues and self-regulation [10], [52]. In this sense, Haworth (2016) believes that PLEs are Web 2.0 and social media tools that empower learners to achieve their learning [148].

\section{LIMITATIONS}

Meanwhile, to the best of our knowledge, this review has also encountered some shortcomings and challenges which need further study in the future. The overwhelming number of published papers may los relevant articles; several literature review studies face this issue. Moreover, the effort to build research by identifying keywords is critical to the search process.

The keyword identification technique was implemented using the snowball process to determine the implications or keywords relevant to the study. Articles can also be overlooked by removing relevant information or keyword sets because of the limited time frame.

Nevertheless, the study also faces potential constraints arising from selection criteria. For instance, this study focused only on journal articles and was limited to documents written only in English. Thus, other relevant articles not written in English and were not published in journals may not be included.

\section{THEORETICAL PERSPECTIVES}

Our review showed that the most common theoretical perspectives in the published articles were self-regulated learning (43 articles), self-directed learning (18 articles), and constructivism (15 articles) (Table II).

The notion of PLEs is relatively novel and still under development. We identify various theoretical aspects of PLEs to participate in the additional growth of their applications. PLEs have strong similarities to personal learning goals. PLEs intend to offer students the opportunity to shape learning environments according to their requirements. The active role of students and self-guidance in their learning was emphasized [15], [31]. 
TABLE II: THE USED THEORETICAL PERSPECTIVE IN THE INCLUDED ARTICLES

\begin{tabular}{|c|c|c|c|}
\hline Theoretical Perspectives & References & Theoretical Perspectives & References \\
\hline Self-regulated learning & $\begin{array}{l}\text { [7], [38[, [41], [43], [48], [54], [56], } \\
{[57],[63],[64],[67],[68],[78],[86],} \\
{[88],[91],[102],[104],[111],[113],} \\
{[115],[119],[121],[122],[132]-[134],} \\
{[136],[137],[139]-[141],[143],[145],} \\
{[147],[168]-[173]}\end{array}$ & Self-efficacy & {$[105]$} \\
\hline Self-directed learning & $\begin{array}{l}{[35],[42],[47],[55],[62],[65],} \\
{[66],[75],[85],[98],[120],[142],} \\
{[150],[154]-[157[,[174]}\end{array}$ & $\begin{array}{l}\text { Transformational leadership } \\
\text { and constructivism }\end{array}$ & {$[175]$} \\
\hline Constructivism & $\begin{array}{l}\text { [33], [39], [45], [49], [79], [84], } \\
{[91],[93],[99],[101],[123],[127],} \\
{[131],[138[,[159]}\end{array}$ & $\begin{array}{l}\text { Connectivism } \\
\text { self-regulated learning }\end{array}$ & {$[75]$} \\
\hline Self-learning & {$[87],[103],[128],[176]$} & Socio-cultural theory & {$[50]$} \\
\hline Lifelong learning & $[125],[151], 161]$ & TAM & {$[61]$} \\
\hline Connectivism & {$[51],[144],[158]$} & $\begin{array}{l}\text { Constructivism } \\
\text { Connectivism }\end{array}$ & [76] \\
\hline Self-Reported Learning & [149], [177] & $\begin{array}{l}\text { Self-directed } \\
\text { Connectivism }\end{array}$ & [53] \\
\hline Lifelong theory & [59] & $\begin{array}{l}\text { Technology-enhanced } \\
\text { learning }\end{array}$ & [178] \\
\hline Personal construct theory & [179] & $\begin{array}{l}\text { Technology acceptance } \\
\text { models }\end{array}$ & {$[152]$} \\
\hline Self-disclosure learning & [129] & Situated Learning & {$[82]$} \\
\hline Collaborative learning & [106] & $\begin{array}{l}\text { Constructivism+ Searle's } \\
\text { theory }\end{array}$ & [112] \\
\hline Mobile learning theories & [72] & Epistemological & [180] \\
\hline
\end{tabular}

This is strongly associated with personalized learning goals by leveraging students' diverse capabilities, strengths, and interests to enhance participation and realize potential [181]. Personalization emphasizes learning as students are encouraged to present their exclusive concepts and backgrounds to the learning condition as resources that the entire class can use [182]. Leadbeater (2004) realizes personalization on a more comprehensive general level and describes a situation in which various public services, such as schools, are environments in which students make decisions regarding their learning in a particular, self-administered manner. Similar goals are associated with the idea of PLEs [183].

Furthermore, the use of PLEs has the probability of promoting so-called 'ownership'. Attwell (2007) argues that PLEs are student-controlled learning spaces [31].

Mott (2010) also stresses students' self-regulating role by describing PLEs as matrices of resources created, chosen and organized by students [184].

Such definitions stress student responsibility, control and modification of learning spaces and learning methods. The descriptions correspond with the Jonassen and Rohrer-Murphy (1999) visions of ownership, giving students the ability to define and control their learning goals and methods. It is said that ownership in these conditions provides students with more useful learning experiences [185].

Tolmie and Boyle (2000) denote ownership influencing on student activity in participating in learning situations [186].

Similarly, Issroff (2005) and Pintrich and Boyle (1993) claim that confidence in control significantly stimulates students and positively affects their academic performance [187], [188]. It is assumed that student-run PLE with self-structured self-learning increases ownership and emotion control and leads to more helpful learning experiences.
Boekaerts (1999) stated that self-regulated learning is a constructive and self-directed process that focuses on the skills of students beyond knowledge, i.e. learning, planning, implementation, monitoring and evaluation [189]. Hakkarainen et al. (2005) propose that cognitive procedures can be categorized into three levels: Level I includes identification and classification of phenomena and performance of learning practices [190]; Level II involves functions of inquiring and giving explanations, etc.; Level III is the level beyond cognitive emphasized in self-organized learning.

Hakkarainen et al. (2004) stated that the role of students in learning usually remains in lower-level activities, and the role of the teacher includes upper and higher-level processes [190]. The specific goal of using PLEs is to promote beyond knowledge in student activities. Students are responsible for selecting suitable tools and designing content for their environments to promote their learning better.

Such ideas are interesting and raise inquiries about the roles and responsibilities of both students and teachers. The issue of students as self-organized learners employing online resources has been introduced earlier, particularly in the late 1990s before Web 2.0. Lehtinen (1997) defined PLEs as "romantic constructivism", the statement that students are skillful in employing open learning environments, discovering the suitable sources and information, and the most effective learning methods, etc. [191].

\section{CONCLusion}

There is a lack of recent systematic reviews and trend analysis covering a large number of PLEs studies. Therefore, the present systematic review and trend analysis can become a guidance platform for researchers, educators, policymakers or even journal publishers for future research in PLEs research. The current systematic review is significant and 
indispensable in reviewing journal articles that discussed PLEs between 2000 and 2020. The key information extracted from articles included 1) country of the first author, 2) year of publication, 3) category of study objective, 4) study design, 5) the used platforms, 6) theoretical perspectives, 7) the employed data collection instrument, 8) study population, 9) author background. This study reveals that literature on PLEs has progressed from 2000 to 2020; the majorities of PLEs-related articles were published between 2011 and 2020, with the year 2013 having the highest number of the published articles (17 articles), followed by the years 2014 and 2017 as 16 papers were published in each of these two years. We also found that the published PLEs research originated from 46 countries; 26 (17.6\%) were from Spain. The majority of the authors had education, computer science, information technology and engineering backgrounds. This review also showed that numerous platforms had been used in PLEs research, and Web 2.0 was the most commonly used platform in PLEs research. We noted that the most common objectives of the included articles were PLEs custom system development, analysis of the PLEs, description of experiment, investigations, development of factor models, framework development, and examination. The most common theoretical perspectives in the published articles were self-regulated learning, self-directed learning, and constructivism. Conclusion: The current systematic review and trend analysis can become a guidance platform for researchers, educators, policymakers or even journal publishers for future research in the realm of PLEs research.

\section{CONFLICT OF INTEREST}

The author(s) declared no potential conflicts of interest concerning the research, authorship, and/or publication of this article.

\section{AUTHOR CONTRIBUTIONS}

SA and NY conducted the research, analyzed the data, and wrote the paper; all authors had approved the final version.

\section{ACKNOWLEDGMENT}

We would like to thank faculty of Social Sciences \& Humanities, School of Education, Universiti Teknologi Malaysia for supporting this work.

\section{REFERENCES}

[1] T. Brosch and D. Sander, Handbook of Value: Perspectives from Economics, Neuroscience, Philosophy, Psychology and Sociology, Oxford University Press, 2015.

[2] S. H. Schwartz, "Basic individual values: Sources and consequences," Handbook of Value: Perspectives from Economics, Neuroscience, Philosophy, Psychology and Sociology, 2016, pp. 63-84.

[3] B. Olivier and O. Liber, "Lifelong learning: The need for portable personal learning environments and supporting interoperability standards," Bristol: The JISC Centre for Educational Technology Interoperability Standards, Bolton Institute, 2001.

[4] N. Kulathuramaiyer and H. Maurer, "Coping with the copy-paste-syndrome," Universiti Malaysia Sarawak, 2007, pp. 1072-1079.

[5] B. Taraghi, T. Altmann, and M. Ebner, "The world of widgets - An important step towards a personalized learning environment," in Proc. the PLE Conference, 2011.

[6] N. Alalwan, W. M. Al-Rahmi, O. Alfarraj, A. Alzahrani, N. Yahaya, and A. M. Al-Rahmi, "Integrated three theories to develop a model of factors affecting students' academic performance in higher education," Ieee Access, vol. 7, pp. 98725-98742, 2019.

[7] N. Dabbagh and A. Kitsantas, "Personal learning environments, social media, and self-regulated learning: A natural formula for connecting formal and informal learning," The Internet and Higher Education, vol. 15, no. 1, pp. 3-8, 2012.

[8] F. G. K. Yilmaz and R. Yilmaz, "Student opinions about personalized recommendation and feedback based on learning analytics," Technology, Knowledge and Learning, 2020, vol. 25, no. 4, pp. 753-768.

[9] Z. A. Shaikh and S. A. Khoja, "Theoretical underpinnings of the guided personal learning environments model. In fourth international conference on e-learning and distance education," Innovative Learning, Promising Future, Riyadh, Saudi Arabia. 2015.

[10] C. McLoughlin and M. J. Lee, "Personalised and self regulated learning in the Web 2.0 era: International exemplars of innovative pedagogy using social software," Australasian Journal of Educational Technology, 2010. 26(1).

[11] I. Buchem, "Psychological Ownership and Personal Learning Environments: Do sense of ownership and control really matter," in PLE Conference Proceedings, 2012, Citeseer.

[12] M. Harmelen, "Personal learning environments," Sixth International Conference on Advanced Learning Technologies, 2006.

[13] P. Panagiotidis, "Using netvibes as a PLE for language learning," in Proc. 8th International Technology, Education and Development Conference Valencia, Spain, 2014.

[14] W. Ulrich and M. Reynolds, "Critical systems heuristics, in systems approaches to managing change: A practical guide," 2010, Springer, pp. 243-292.

[15] S. Schaffert and W. Hilzensauer, "On the way towards Personal Learning Environments: Seven crucial aspects," Elearning Papers, 2008, vol. 9, no. 2, pp. 1-11.

[16] M. Stec, C. Smith, and E. Jacox, "Technology enhanced teaching and learning: Exploration of faculty adaptation to iPad delivered curriculum," Technology, Knowledge and Learning, 2019, pp. 1-15.

[17] A. Hicks and C. Sinkinson, "Critical connections: personal learning environments and information literacy," 2014.

[18] P. Ibañz, C. Villalonga, and L. Nuere, "Exploring student activity with learning analytics in the digital environments of the Nebrija University," Technology, Knowledge and Learning, 2019, pp. 1-19.

[19] W. A. Burleson, "The roles of personal learning environments and the teacher-librarian in facilitating 21 st century learning: A flexible framework for a high school learning environment," 2015.

[20] C. J. Yen, C. H. Tu, L. E. Sujo-Montes, S. W. Armfield, and J.Y. Chan, "Learner self-regulation and web 2.0 tools management in personal learning environment," International Journal of Web-Based Learning and Teaching Technologies (IJWLTT), 2013, vol. 8, no. 1, pp. 46-65.

[21] W. M. Al-Rahmi, N. Yahaya, A. A. Aldraiweesh, U. Alturki, M. M. Alamri, M. S. B. Saud, Y. B. Kamin, A. A. Aljeraiwi, and O. A. Alhamed, "Big data adoption and knowledge management sharing: An empirical investigation on their adoption and sustainability as a purpose of education," IEEE Access, 2019, vol. 7, pp. 47245-47258.

[22] A. Booth, A. Sutton, and D. Papaioannou, "Systematic approaches to a successful literature review," 2016.

[23] A. Stang, "Critical evaluation of the Newcastle-Ottawa scale for the assessment of the quality of nonrandomized studies in meta-analyses," European journal of epidemiology, 2010, vol. 25, no. 9, pp. 603-605.

[24] D. Moher, A. Liberati, J. Tetzlaff, D. G. Altman, and Prisma Group, "Preferred reporting items for systematic reviews and meta-analyses: the PRISMA statement," PLoS medicine, 2009, vol. 6, no. 7, p. e1000097.

[25] R. T. Kompen, P. Edirisingha, and R. Mobbs, "Putting the pieces together: Conceptual frameworks for building PLEs with Web 2.0 tools," Distance and E-Learning in Transition, 2013, pp. 783-808.

[26] M. P. P. Espinosa, L. C. Quintero, R. O. Beltrán, and X. C. Farran "Componentes básicos para el análisis de los PLE de los futuros profesionales españoles: en los albores del Proyecto CAPPLE. EDUTEC," Revista Electrónica de Tecnología Educativa, 2014, no. 47, pp. a264-a264.

[27] F. Pais, C. Santos, and L. Pedro, "Innovation, knowledge and sustainability with PLEs: An empirical analysis from SAPO Campus Schools pilots," Learning and Diversity in the Cities of the Future, 2014, p. 115.

[28] E. Rahimi, J. Berg, and W. Veen, "Facilitating student-driven constructing of learning environments using Web 2.0 personal learning environments," Computers \& Education, 2015, vol. 81, pp. 235-246.

[29] P. R. Humanante-Ramos, F. J. García-Peñalvo, and M. Á "Conde-gonzález, electronic devices and web 2.0 tools: Usage trends in 
engineering students," International Journal of Engineering Education (IJEE), 2017, vol. 33, no. 2B, pp. 790-796.

[30] S. Downes, "Learning networks and connective knowledge, in collective intelligence and e-learning 2.0: Implications of web-based communities and networking," IGI Global, pp. 1-26, 2010.

[31] G. Attwell, "Personal learning environments-the future of elearning," Elearning Papers, 2007, vol. 2, no. 1, pp. 1-8.

[32] B. Taraghi, M. Ebner, and S. Schaffert, "Personal learning environments for higher education: A mashup based widget concept," in F. Wild, M. Kalz, M. Palmér, \& D. Müler (Éd.), Mash-Up Personal Learning Environments: Proceedings of the Workshop in conjunction with the 4th European Conference on Technology-Enhanced Learning (ECTEL'09), 2009, Citeseer.

[33] C. Severance, J. Hardin, and A. Whyte, "The coming functionality mash-up in personal learning environments," Interactive Learning Environments, vol. 16, no. 1, pp. 47-62, 2008.

[34] U. Ehlers and R. Carneiro, "Personal learning environments," eLearning Papers, no. 9, 2008.

[35] M. Johnson and O. Liber, "The personal learning environment and the human condition: from theory to teaching practice," Interactive Learning Environments, vol. 16, no. 1, pp. 3-15, 2008.

[36] E. Rahimi, J. Berg, and W. Veen, "A learning model for enhancing the student's control in educational process using web 2.0 personal learning environments," British Journal of Educational Technology, 2015, vol 46, no. 4, pp. 780-792.

[37] C. Keereerat, J. Na-Songkhla, and S. Sujiva, "A study of creating personal learning environments by students of the faculty of education majoring in computer education," Journal of Education Studies, 2019 , vol. 47, no. 4, pp. 176-196.

[38] M. L. Cejudo, "Assessing personal learning environments (PLEs). An expert evaluation," Journal of New Approaches in Educational Research (NAER Journal), 2013, vol. 2, no. 1.

[39] P. P. Sanchez-Villalon, and M. Ortega, "AWLA and AIOLE for personal learning environments," International Journal of Continuing Engineering Education and Life Long Learning, 2007, vol. 17, no. 6, pp. $418-431$

[40] M. W. Johnson and D. Sherlock, "Beyond the personal learning environment: Attachment and control in the classroom of the future," Interactive Learning Environments, 2014, vol. 22, no. 2, pp. 146-164.

[41] N. Dabbagh and H. Fake, "College students' perceptions of personal learning environments through the lens of digital tools, processes and spaces," Journal of New Approaches in Educational Research (NAER Journal), 2017, vol. 6, no. 1, pp. 28-36.

[42] J. A. García-Martínez, F. C. Rosa-Napal, I. Romero-Tabeayo, S. López-Calvo, and E. J. Fuentes-Abeledo, "Digital tools and personal learning environments: An analysis in higher education," Sustainability, 2020, vol. 12 , no. 19 , p. 8180.

[43] S. Kroop, "Evaluation on students' and teachers' acceptance of widget-and cloud-based personal learning environments," Journal of Universal Computer Science, 2013, vol. 19, no. 14, pp. 2150-2171.

[44] M. Ross, "Welsh, Formative feedback to improve learning on a teacher education degree using a personal learning environment," International Journal of Emerging Technologies in Learning (iJET), 2007, vol. 2 , no. 3.

[45] J. C. Almenara and V. M. Díaz, "ICT training of university teachers in a personal learning environment. Project DIPRO 2.0," Journal of New Approaches in Educational Research (NAER Journal), 2012, vol. 1, no. 1.

[46] M. M. Baig, "LearnOnline: Personal learning environment implementation in University of South Australia," International Journal of Knowledge Society Research (IJKSR), 2013, vol. 4, no. 2, pp 19-26.

[47] M. J. Rodrıguez-Triana, A. Martınez-Monés, and J. I. Asensio-Pérez, "Monitoring collaboration in flexible and personal learning environments," Interaction, Design and Architecture (s) Journal, special issue on: Evaluating Educative Experiences of Flexible and Personal Learning Environments, 2011, vol. 11, no. 12, pp. 51-63.

[48] S. H. Fiedler and T. Väljataga, "Personal learning environments: concept or technology?" International Journal of Virtual and Personal Learning Environments (IJVPLE), 2011, vol. 2, no. 4, pp. 1-11.

[49] Z. A. Shaikh and S.A. Khoja, "Personal learning environments and university teacher roles explored using Delphi," Australasian Journal of Educational Technology, 2014, vol. 30, no. 2.

[50] L. Castañeda, N. Dabbagh, and R. Torres-Kompen, "Personal learning environments: Research-based practices, frameworks and challenges," 2017.
[51] M. C. Pettenati, "Roadmap to PLE: A design and development route to empower the use of personal learning environments (PLEs)," Interaction Design and Architecture (s) Journal, vol. 9, p. 10.

[52] Z. A. Shaikh and S. A. Khoja, "Role of teacher in personal learning environments," Digital Education Review, 2012, pp. 23-32.

[53] G. M. S. Ferreira and R. G. M. Castiglione, "ICT in education: Personal learning environments in perspectives and practices of young people," Educ. Pesqui, 2018, vol. 44, p. e153673.

[54] J.-Y. Wu, "The indirect relationship of media multitasking self-efficacy on learning performance within the personal learning environment: Implications from the mechanism of perceived attention problems and self-regulation strategies," Computers \& Education, 2017, vol. 106, pp. 56-72.

[55] W. Drexler, "The networked student model for construction of personal learning environments: Balancing teacher control and student autonomy," Australasian Journal of Educational Technology, 2010, vol. 26, no. 3 .

[56] E. Isaksson, A. Naeve, P. Lefrère, and F. Wild, "Towards a reference architecture for smart and personal learning environments," Innovations in Smart Learning, 2017, Springer, Singapore, pp. 81-90.

[57] E. Tsui and N. Dragicevic, "Use of scenario development and personal learning environment and networks (PLE\&N) to support curriculum co-creation," Management \& Marketing, 2018, vol. 13, no. 2, pp. 848.

[58] R. Godwin-Jones, "Personal learning environments," Language Learning \& Technology, 2009, vol. 13, no. 2, pp. 3-9.

[59] S. H. Abualoush, A. M. Obeidat, A. Tarhini, R. E. Masa'deh, and A. Al-Badi, "The role of employees' empowerment as an intermediary variable between knowledge management and information systems on employees' performance," VINE Journal of Information and Knowledge Management Systems, 2018, vol. 48, no. 2, pp. 217-237

[60] M. Saadatmand and K. Kumpulainen, "Content aggregation and knowledge sharing in a personal learning environment: Serendipity in open online networks," International Journal of Emerging Technologies in Learning (iJET), 2013, vol. 8.

[61] T. Valtonen, S. Hacklin, P. Dillon, M. Vesisenaho, J. Kukkonen, and A Hietanen, "Perspectives on personal learning environments held by vocational students," Computers \& Education, 2012, vol. 58, no. 2, pp. 732-739.

[62] C. Patterson, M. Stephens, V. Chiang, A. M. Price, F. Work, and E. Snelgrove-Clarke, "The significance of personal learning environments (PLEs) in nursing education: Extending current conceptualizations," Nurse education today, 2017, vol. 48, pp. 99-105.

[63] V. M. Juarros, J. S. Ibáñez, and B. B. Crosetti, "Research results of two personal learning environments experiments in a higher education institution," Interactive learning environments, 2014, vol. 22, no. 2, pp. 205-220.

[64] S. Armakolas, A. Mikroyannidis, C. Panagiotakopoulos, and T Panousopoulou, "A case study on the Perceptions of Educators on the Penetration of Personal Learning Environments in Typical Education," International Journal of Virtual and Personal Learning Environments (IJVPLE), 2016, vol. 6, no. 1, pp. 18-28.

[65] A. Ruengkul and P. Sukavatee, "A survey study of personal learning environment tools for English language learning of Thai Efl undergraduate students," PEOPLE: International Journal of Social Sciences, 2015, vol. 1, no. 1, pp. 91-101.

[66] M. Tomé-Fernández, M. García-Garnica, A. Martínez-Martínez, and E M. Olmedo-Moreno, "An analysis of personal learning environments and age-related psychosocial factors of unaccompanied foreign minors," International Journal of Environmental Research and Public Health, 2020, vol. 17, no. 10, p. 3700 .

[67] J. D. Basham, T. E. Hall, R. A. Carter Jr, and W. M. Stahl, "An operationalized understanding of personalized learning," Journal of Special Education Technology, 2016, vol. 31, no. 3, pp. 126-136.

[68] M. Á. Conde and Á. "Hernández-García, "Data driven education in personal learning environments-what about learning beyond the institution?" International Journal of Learning Analytics and Artificial Intelligence for Education (iJAI), 2019, vol. 1, no. 1, pp. 43-57.

[69] B. J. Parra, "Learning strategies and styles as a basis for building personal learning environments," International Journal of Educational Technology in Higher Education, 2016, vol. 13, no. 1, pp. 1-11.

[70] M. Goram and D. Veiel, "Linking legal and domain-specific requirements in a context-based adaptive personalized learning environment," Procedia Computer Science, 2020, vol. 170, pp. 995-1002.

[71] S. White and H. C. Davis, "Making it rich and personal: crafting an institutional personal learning environment, in technologies, innovation, and change in personal and virtual learning environments," IGI Global, 2013, pp. 177-192. 
[72] A. El-Magd and M. A. E.-M. Mohammad, "A task-based personal learning environment for developing the english majors listening comprehension skills," pp.1-40, 2005.

[73] M. Á. C. González and F. J. Garcia-Penalvo, "Mobile personal learning applied to a software engineering subject," IEEE Revista Iberoamericana de Tecnologías del Aprendizaje, vol. 9, no. 3, pp. 114-121, July 2014.

[74] B. Balakrishnan, "Motivating engineering students learning via monitoring in personalized learning environment with tagging system,' Computer Applications in Engineering Education, 2018, vol. 26, no. 3, pp. 700-710.

[75] J. Bidarra and J. Araújo, "Personal learning environments (PLEs) in a distance learning course on mathematics applied to business," European Journal of Open, Distance and E-learning, 2013, vol. 16, no. 1, pp. 141-152.

[76] N. A. Drajati and A. Handayani, "Promoting personal learning environment for emerging academic writing for publication for higher education students," Register Journal, 2020, vol. 13, no. 2, pp. 293-314.

[77] R. Archee, "Reflections on personal learning environments: Theory and practice," Procedia-Social and Behavioral Sciences, 2012, vol. 55, pp. $419-428$.

[78] J. L. Carrasco-Sáez, M. Careaga Butter, M. G. Badilla-Quintana, L. Jiménez Pérez, and J. Molina Farfánm "Sociological importance and validation of a questionnaire for the sustainability of Personal Learning Environments (PLE) in 8th grade students of the Biobío region in Chile," Sustainability, 2019, vol. 11, no. 5, p. 1301

[79] M. Tomé, L. Herrera, and S. Lozano, "Teachers' opinions on the use of personal learning environments for intercultural competence," Sustainability, 2019, vol. 11, no. 16, p. 4475.

[80] A. Berqia, "Teaching power electronics and digital electronics using personal learning environments," Journal of Mobile Multimedia, 2017 , vol. 12 , no. $3 \& 4$, pp. $244-255$.

[81] F. Rejón-Guardia, A. I. Polo-Peña, and G. Maraver-Tarifa, "The acceptance of a personal learning environment based on Google apps: The role of subjective norms and social image," Journal of Computing in Higher Education, 2020, vol. 32, no. 2, pp. 203-233.

[82] E. Ehiyazaryan-White, "The dialogic potential of ePortfolios: Formative feedback and communities of learning within a personal learning environment," International Journal of ePortfolio, 2012, vol. 2, no. 2, pp. 173-185.

[83] A. I. M. Elfeky, "The effect of personal learning environments on participants' higher order thinking skills and satisfaction," Innovations in Education and Teaching International, 2018.

[84] F. J. García-Peñalvo and M. Á. Conde, "The impact of a mobile personal learning environment in different educational contexts," Universal Access in the Information Society, 2015, vol. 14, no. 3, pp. 375-387.

[85] M. Ivanova and M. A. Chatti, "Toward a model for the conceptual understanding of personal learning environments: A case study," Journal of Educational Technology Systems, 2011, vol. 39, no. 4, pp. 419-439.

[86] R. M. R. Hussain and H. Z. Ng, "Training academicians to develop personalized learning environment and students engagement (PLEaSE," International Journal of Virtual and Personal Learning Environments (IJVPLE), 2013, vol. 4, no. 4, pp. 16-30.

[87] S. Tanyong and M. A. Sharafuddin, "Understanding personal learning environment perspectives of Thai international tourism and hospitality higher education students," Journal of Education and Practice, 2016, vol. 7 , no. 10 , pp. 128-139.

[88] M. Ivanova, "Use of start pages for building a mashup personal learning environment to support self-organized learners," Serdica journal of Computing, 2009, vol. 3, no. 3, pp. 227-238.

[89] M. P. D'Alessandro, “Connecting your radiology learning to your clinical practice: using personal learning environments, learning portfolios and communities of practice," Pediatric Radiology, 2011, vol. 41 , no. 1, pp. 245-246.

[90] E. W. C. Leung and Q. Li, "An experimental study of a personalized learning environment through open-source software tools," IEEE Transactions on Education, 2007, vol. 50, no. 4, pp. 331-337.

[91] D. Xu, H. Wang, and M. Wang, "A conceptual model of personalized virtual learning environments," Expert Systems with Applications, 2005, vol. 29, no. 3, pp. 525-534.

[92] S. Chookaew, P. Panjaburee, D. Wanichsan, and P. Laosinchai, "A personalized e-learning environment to promote student's conceptual learning on basic computer programming," Procedia-Social and Behavioral Sciences, 2014, vol. 116, pp. 815-819.
[93] E. Koulocheri and M. Xenos, "Correlating formal assessment with social network activity within a personal learning environment," International Journal of Web-Based Learning and Teaching Technologies (IJWLTT), 2019, vol. 14, no. 1, pp. 17-31.

[94] P. Sengottuvelan, T. Gopalakrishnan, R. L. Kumar, and M. Kavya, “A recommendation system for personal learning environments based on learner clicks," International Journal of Applied Engineering Research, 2015, vol. 10, pp. 15316-15321.

[95] J. W. Li, Y. C. Chang, C. P. Chu, and C. C. Tsai, "A self-adjusting e-course generation process for personalized learning," Expert Systems with Applications, 2012, vol. 39, no. 3, pp. 3223-3232.

[96] B. Guettat and R. Farhat, "An approach to assist learners to identify their learning objectives in personal learning environment (PLE)," 2015 5th International Conference on Information \& Communication Technology and Accessibility (ICTA), IEEE, 2015.

[97] M. Salehi, I. N. Kamalabadi, and M. B. G. Ghoushchi, "An effective recommendation framework for personal learning environments using a learner preference tree and a GA," IEEE Transactions on Learning Technologies, 2013, vol. 6, no. 4, pp. 350-363.

[98] N. Haristiani and M. M. Rifa'i, "Combining chatbot and social media: Enhancing personal learning environment (PLE) in language learning," Indonesian Journal of Science and Technology, vol. 5, no. 3, pp. 487-506

[99] D. Xu, W. W. Huang, H. Wang, and J. Heales, "Enhancing e-learning effectiveness using an intelligent agent-supported personalized virtual learning environment: An empirical investigation," Information \& Management, 2014, vol. 51, no. 4, pp. 430-440.

[100]N. Marianos, M. Ungur, and N. Manouselis, "Evaluating a personal learning environment for digital storytelling," Interaction Design and Architecture(s) Journal (IxD\&A), 2011, vol. 11, pp. 37-50.

[101]F. Y. Yang and C.-C. Chang, "Examining high-school students' preferences toward learning environments, personal beliefs and concept learning in web-based contexts," Computers \& Education, 2009 , vol. 52 , no. 4 , pp. $848-857$

[102]V. M. Diaz, A. I. V. Martinez, and K. J. McMullin, "First steps towards a university social network on personal learning environments," The International Review of Research in Open and Distributed Learning, 2014, vol. 15, no. 3)

[103]J. Bidarra and N. Sousa, "Implementing mobile learning within personal learning environments: A study of two online courses," The International Review of Research in Open and Distributed Learning, 2020, vol. 21, no. 4, pp. 181-198

[104]M. Johnson, D. Prescott, and S. Lyon, "Learning in online continuing professional development: An institutionalist view on the personal learning environment," Journal of New Approaches in Educational Research (NAER Journal), 2017, vol. 6, no. 1, pp. 20-27.

[105]T. Väljataga and M. Laanpere, "Learner control and personal learning environment: A challenge for instructional design," Interactive Learning Environments, 2010, vol. 18, no. 3, pp. 277-291

[106]M. A. Sharafuddin, B. P. Sawad, and S. Wongwai, "Modeling and mapping personal learning environment of Thai international higher education students," Asian Journal of Education and Training, 2018, vol. 4 , no. 1 , pp. $35-40$.

[107]J. G. Martnez, E. Rigo, and R. Jimnez, "Multimedia and textual reading comprehension: Multimedia as personal learning environment's enriching format," Journal of New Approaches in Educational Research (NAER Journal), 2017, vol. 6, no. 1, pp. 3-10.

[108]R. T. Kompen, P. Edirisingha, X. Canaleta, M. Alsina, and J. M Monguet, "Personal learning environments based on web 2.0 services in higher education," Telematics and informatics, 2019, vol. 38, pp. 194-206.

[109]M. Moreno, "Personal learning environments that facilitate socio-educational integration of unaccompanied foreign minors," International Journal of Environmental Research and Public Health, 2020, vol. 17, no. 14, p. 5012.

[110]C. Harwood, "Personal learning environments: using symbalooedu in learning English for academic purposes," Journal of English for Specific Purpose at Tertiary Level, 2014, vol. 2, no. 2, pp. 99-215.

[111]C. K. N. C. K. Mohd and F. Shahbodin, "Personalized learning environment: Alpha testing, Beta Testing \& user acceptance test," Procedia-Social and Behavioral Sciences, 2015, vol. 195, pp. 837-843.

[112]A. M. Korhonen, S. Ruhalahti, and M. Veermans, "The online learning process and scaffolding in student teachers' personal learning environments," Education and Information Technologies, 2019, vol. 24, no. 1, pp. 755-779.

[113]M. W. Johnson, "The personal learning environment and the institution of education: reflections on technological personalisation in iTEC 
schools," International Journal of Smart Technology and Learning, 2016, vol. 1, no. 1, pp. 93-106.

[114]M. A. Chatti, M. R. Agustiawan, M. Jarke, and M. Specht, "Toward a personal learning environment framework," International Journal of Virtual and Personal Learning Environments (IJVPLE), 2010, vol. 1, no. 4 , pp. 66-85

[115]F. Mödritscher, "Towards a recommender strategy for personal learning environments," Procedia Computer Science, 2010, vol. 1, no. 2, pp. 2775-2782.

[116]R. H. Rizzardini, B. H. Linares, A. Mikroyannidis, and H. C. Schmitz, "Cloud services, interoperability and analytics within a ROLE-enabled personal learning environment," J.UCS Journal of Universal Computer Science, 2013, vol. 19, no. 14, pp. 2054-2074.

[117]N. M. Tuah, D. S. Ajor, and N. Jamil, "Assistive tools towards personal learning environment in higher education," International Journal of Computer Theory and Engineering, 2015, vol. 7, no. 5.

[118]L. Castañeda and J. Soto, "Building personal learning environments by using and mixing ICT tools in a professional way," Digital Education Review, 2010, vol.18, pp. 9-25.

[119]F. Di Cerbo, G. Dodero, and L. Papaleo, "Experiencing personal learning environments and networks using a 3D space metaphor," Interaction Design and Architecture(s) Journal (IxD\&A), 2011, vol. 11, pp. 64-76.

[120]S. Fiedler and T. Väljataga, "Personal learning environments: a conceptual landscape revisited," E-Learning papers, 2013, vol. 35, pp. $1-16$.

[121]P. R. Humanante-Ramos, F. J. García-Peñalvo, and M. Á. Conde-González, "Personal learning environments and online classrooms: An experience with university students," IEEE Revista Iberoamericana de tecnologías del aprendizaje, 2015, vol. 10, no. 1, pp. 26-32.

[122]S. Şahin and Ç. Uluyol, "Preservice teachers' perception and use of personal learning environments (PLEs)," International Review of Research in Open and Distributed Learning, 2016, vol. 17, no. 2, pp. 141-161.

[123]P. Bouchard and M. Qc, "The problem of learner control in networked personal learning environments," International Journal of Learning and Technology, 2014, vol. 15, no. 2.

[124]C. B. Yao, "Constructing a user-friendly and smart ubiquitous personalized learning environment by using a context-aware mechanism," IEEE Transactions on Learning Technologies, 2015, vol. 10, no. 1, pp. 104-114.

[125]E. R. Frías and J. L. A. Montaño, "A view on personal learning environments through approaches to learning," The International Journal for Innovation and Quality in Learning, vol. 1, pp. 29-368, 2013.

[126]K. Halimi, H. Seridi-Bouchelaghem, and C. Faron-Zucker, "An enhanced personal learning environment using social semantic web technologies," Interactive Learning Environments, 2014, vol. 22, no. 2 , pp. 165-187.

[127]S. M. Ali, I. Ghani, and M. S. Abd Latiff, "Interaction-based collaborative recommendation: a personalized learning environment (PLE) perspective," KSII Transactions on Internet and Information Systems (TIIS), 2015, vol. 9, no. 1, pp. 446-465.

[128]M. A. Chatti, M. Jarke, M. Specht, U. Schroeder, and D. Dahl, "Model-driven mashup personal learning environments," International Journal of Technology Enhanced Learning, 2011, vol. 3, no. 1, pp. 21-39.

[129]A. Alenezi, "Open learning: Key foundations of personal learning environment," International Journal on Web Service Computing (IJWSC), 2019, vol. 10, no. 1/2.

[130]C. Kim, "Out-of-class communication and personal learning environments via social media: Students' perceptions and implications for faculty social media use," Teaching Journalism \& Mass Communication, 2017, vol. 7, no. 1, p. 62.

[131]S. Wilson, O. Liber, M. Johnson, P. Beauvoir, P. Sharples, and C. Milligan, "Personal Learning Environments: Challenging the dominant design of educational systems," Journal of E-learning and Knowledge Society, 2007, vol. 3, no. 2, pp. 27-38.

[132]J. Charteris, M. Parkes, S. Gregory, P. Fletcher, and V. Reyes, "Student-initiated Facebook sites: Nurturing personal learning environments or a place for the disenfranchised?" Technology, Pedagogy and Education, 2018, vol. 27, no. 4, pp. 459-472.

[133]I. Pulak, "Traditional and digital personal learning environment in experiences of university students," International Journal of Continuing Engineering Education and Life Long Learning, 2016, vol. 26, no. 4, pp. 419-433.
[134]C. J. Yen, C. H. Tu, L. E. Sujo-Montes, H. Harati, and C. R. Rodas, "Using personal learning environment (PLE) management to support digital lifelong learning," International Journal of Online Pedagogy and Course Design (IJOPCD), 2019, vol. 9, no. 3, pp. 13-31.

[135]N. Dabbagh, A. Kitsantas, M. Al-Freih, and H. Fake, "Using social media to develop personal learning environments and self-regulated learning skills: A case study," International Journal of Social Media and Interactive Learning Environments, 2015, vol. 3, no. 3, pp. 163-183.

[136]J.Y. Wu, Y.-C. Hsiao, and M.-W. Nian, "Using supervised machine learning on large-scale online forums to classify course-related Facebook messages in predicting learning achievement within the personal learning environment," Interactive Learning Environments, 2020, vol. 28, no. 1, pp. 65-80.

[137]M. P. Prendes-Espinosa, L. Castañeda-Quintero, I. M. Solano Fernández, R. Roig-Vila, M. Aguiar Perera, and J. L. Serrano-Sánchez, "Implementation and design of a service-based framework to integrate personal and institutional learning environments," Science of Computer Programming, 2014, vol. 88, pp. 41-53.

[138]M. P. P. Espinosa, L. Castañeda, I. Solano, R. Roig, A. M ${ }^{\mathrm{a}}$ Victoria, and J. L. S. Sánchez, "Validation of a questionnaire on work and learning habits for future professionals: Exploring personal learning environments," 2016.

[139]J. L. Arquero, S. Barrio-García, and E. Romero-Frías, "What drives students' loyalty-formation in social media learning within a personal learning environment approach? The moderating role of need for cognition," Journal of Educational Computing Research, 2017, vol. 55, no. 4, pp. $495-525$

[140]M. N. Ndongfack, "Design and development of a personal learning environment for corporate self-regulated learning," Journal of Computer and Communications, 2016, pp. 1-9.

[141]M. Á. Conde, F. J. García-Peñalvo, M. Alier, and J. Piguillem, "The implementation, deployment and evaluation of a mobile personal learning environment," Journal of Universal Computer Science, 2013 , vol. 19 , no. 7, pp. 854-872.

[142]K. Žubrinić and D. Kalpić, "The web as personal learning environment," International Journal of Emerging Technologies in Learning, 2008, vol. 3 .

[143]J. Y. Wu and T. Cheng, "Who is better adapted in learning online within the personal learning environment? Relating gender differences in cognitive attention networks to digital distraction," Computers \& Education, 2019, vol. 128, pp. 312-329.

[144]R. Kop and H. Fournier, "Developing a framework for research on Personal Learning Environments," E-Learning in Europe Journal, 2014, vol. 35, pp. 13-17.

[145]J. Fiaidhi, S. Mohammed, L. Chamarette, and D. Thomas, "Identifying middlewares for mashup personal learning environments," Future Internet, 2009, vol. 1, no. 1, pp. 14-27.

[146]N. S. M. Salleh, A. A. Karim, M. A. T. Mazzlida, S. Z. A. Manaf, N. F. J. N. Ramlan, and A. Hamdan, "An evaluation of content creation for personalised learning using digital ICT literacy module among aboriginal students (MLICT-OA)," Turkish Online Journal of Distance Education, 2019, vol. 20, no. 3, pp. 41-58.

[147]S. Wilson, "Patterns of personal learning environments," Interactive Learning Environments, 2008, vol. 16, no. 1, pp. 17-34.

[148]R. Haworth, "Personal learning environments: A solution for self-directed learners," TechTrends, 2016, vol. 60, no. 4, pp. 359-364.

[149]R. Schmid and D. Petko, "Does the use of educational technology in personalized learning environments correlate with self-reported digital skills and beliefs of secondary-school students?" Computers \& education, 2019, vol. 136, pp. 75-86.

[150]C. Coll and A. Engel, "Introduction: Personal learning environments in the context of formal education/Introducción: los Entornos Personales de Aprendizaje en contextos de educación formal," Cultura y Educación, 2014, vol. 26, no. 4, pp. 617-630.

[151]I. Laakkonen and P. Taalas, "Towards new cultures of learning: Personal learning environments as a developmental perspective for improving higher education language courses," Language Learning in Higher Education, 2015, vol. 5, no. 1, pp. 223-241.

[152]U. P. Muthupoltotage and L. Gardner, "Technology acceptance within informal personal learning environments: A qualitative analysis," Technology, 2019, vol. 6, pp. 15-2019.

[153]V. Tomberg, M. Laanpere, T. Ley, and P. Normak, "Sustaining teacher control in a blog-based personal learning environment," International Review of Research in Open and Distributed Learning, 2013, vol. 14, no. 3, pp. 109-133.

[154]M. A. Chatti, S. Dakova, H. Thüs, and U. Schroeder, "Tag-based collaborative filtering recommendation in personal learning 
environments," IEEE Transactions on learning technologies, 2013, vol. 6, no. 4, pp. 337-349.

[155]P. Conradie, "Supporting self-directed learning by connectivism and personal learning environments," International Journal of Information and Education Technology, 2014, vol. 4, no. 3, p. 254.

[156]H. T. Kahraman, S. Sagiroglu, and I. Colak, "Novel user modeling approaches for personalized learning environments," International Journal of Information Technology \& Decision Making, 2016, vol. 15, no. 03 , pp. 575-602.

[157]E. Reategui, E. Boff, and J. A. Campbell, "Personalization in an interactive learning environment through a virtual character," Computers \& Education, 2008, vol. 51, no. 2, pp. 530-544.

[158]J. Cabero-Almenara and A. I. Vázquez-Martínez, "Production and evaluation of a Personal Learning Environment for faculty training: Analysis of an experience/Producción y evaluación de un Entorno Personal de Aprendizaje para la formación universitaria: análisis de una experiencia," Cultura y Educación, 2014, vol. 26, no. 4, pp. 631-659.

[159]T. M. Simões, J. J. Rodrigues, and I. Torre, "Personal learning environment box (PLEBOX): A new approach to e-learning platforms," Computer Applications in Engineering Education, 2013, vol. 21, no. S1, pp. E100-E109.

[160]H. C. Barrett and N. Garrett, "Online personal learning environments: Structuring electronic portfolios for lifelong and life-wide learning," On the Horizon, 2009.

[161]V. Marín-Díaz, M. López-Pérez, and B. E. Sampedro-Requena, "Personal learning environment within the lecture room: a contribution from the halls of childhood education degree," Procedia-Social and Behavioral Sciences, 2017, vol. 237, pp. 360-364.

[162]K. Nikolopoulou, V. Gialamas, K. Lavidas, and V. Komis, "Teachers' readiness to adopt mobile learning in classrooms: A study in Greece," Technology, Knowledge and Learning, 2020, pp. 1-25.

[163]A. J. Berlanga, P. B. Sloep, L. Kester, F. Brouns, P. Rosmalen, and R. Koper, "Ad hoc transient communities: Towards fostering knowledge sharing in learning networks," International Journal of Learning Technology, 2008, vol. 3, no. 4, pp. 443-458.

[164]G. Zhu, W. Liu, and S. Zhang, "Designing personalized learning difficulty for online learners," International Conference on Web-Based Learning, 2010, Springer.

[165]D. Henriksen, M. Henderson, E. Creely, S. Ceretkova, M. Černochová, E. Sendova, E. T. Sointu, and C. H. Tienken, "Creativity and technology in education: An international perspective," Technology, Knowledge and Learning, 2018, vol. 23, no. 3, pp. 409-424.

[166]K. Verbert, N. Manouselis, H. Drachsler, and E. Duval, "Dataset-driven research to support learning and knowledge analytics," Educational Technology \& Society, 2012, vol. 15, no. 3, pp. 133-148.

[167]S. Dawson, "'Seeing' the learning community: An exploration of the development of a resource for monitoring online student networking," British Journal of Educational Technology, 2010, vol. 41, no. 5, pp. 736-752.

[168]J. DeMink-Carthew, M. W. Olofson, L. LeGeros, S. Netcoh, and S. Hennessey, "An analysis of approaches to goal setting in middle grades personalized learning environments," RMLE Online, 2017, vol. 40, no. 10 , pp. 1-11.

[169]A. Martínez-Martínez, M. D. C. Olmos-Gómez, M. Tomé-Fernández, and E. M. Olmedo-Moreno, "Analysis of psychometric properties and validation of the personal learning environments questionnaire (PLE) and social integration of unaccompanied foreign minors (MENA)," Sustainability, 2019, vol. 11, no. 10, p. 2903.

[170]A. Engel, A. Saz, and C. C. Salvador, "Introducing a personal learning environment in higher education. An analysis of connectivity," Digital Education Review, 2016, no. 29, p. 1-14.

[171]P. L. Davidson, "Personal learning environments and the diversity of digital natives," Open Access Library Journal, 2017, vol. 4, no. 5, pp. 1-7.

[172]D. Verpoorten, C. Glahn, M. Chatti, W. Westera, and M. Specht, "Self-reported learning effects of a tagging activity carried out in a personal learning environment (PLE) by secondary-school pupils," International Journal for Cross-Disciplinary Subjects in Education, 2011, vol. 2, no. 1, pp. 276-284.

[173]M. Tomé-Fernández, E. Curiel-Marín, and E. Caraballo, "Use of mobile technologies in personal learning environments of intercultural contexts: Individual and group tasks," Electronics, 2020, vol. 9, no. 5, p. 876.

[174]Y. Cao, D. Kovachev, R. Klamma, M. Jarke, and R. W. Lau, "Tagging diversity in personal learning environments," Journal of Computers in Education, 2015, vol. 2, no. 1, pp. 93-121.
[175]Y. Jiang, S. E. Jackson, and S. Colakoglu, "An empirical examination of personal learning within the context of teams," Journal of Organizational Behavior, 2016, vol. 37, no. 5, pp. 654-672.

[176]P. A. Bishop, J. M. Downes, S. Netcoh, K. Farber, J. DeMink-Carthew, T. Brown, and R. Mark, "Teacher roles in personalized learning environments," The Elementary School Journal, 2020, vol. 121, no. 2 , pp. 311-336.

[177]J. E. López, J. J. R.-D. Guardia, M. D. C. Olmos-Gómez, R Chacón-Cuberos, and E. M. Olmedo-Moreno, "Enhancing skills for employment in the workplace of the future 2020 using the theory of connectivity: shared and adaptive personal learning environments in a Spanish context," Sustainability, 2019, vol. 11, no. 15, p. 4219.

[178]M. Gourmaj, A. Naddami, A. Fahli, and D. Nehari, "Teaching power electronics and digital electronics using personal learning environments: From traditional learning to remote experiential learning," International Journal of Online Engineering, 2017, vol. 13, no. 8 .

[179]M. W. Johnson, S. Rodriguez-Arciniegas, and A. N. Kataeva "Comparative judgement and the visualisation of construct formation in a personal learning environment," Interactive Learning Environments, 2020, pp. 1-20.

[180]T. Martindale and M. Dowdy, "Personal learning environments," Emerging technologies in distance education, 2010, pp. 177-193.

[181]D. Loi, and P. "Dillon, Adaptive educational environments as creative spaces," Cambridge Journal of Education, 2006, vol. 36, no. 3, pp. 363-381.

[182]R. J. Campbell, W. Robinson, J. Neelands, R. Hewston, and L. Mazzoli, "Personalised learning: Ambiguities in theory and practice," British Journal of Educational Studies, 2007, vol. 55, no. 2, pp. 135-154.

[183]C. Leadbeater, "Personalisation through participation: A new script for public services," 2004, Demos.

[184]J. Mott, "Envisioning the post-LMS era: The open learning network," Educause Quarterly, 2010, vol. 33, no. 1, pp. 1-9.

[185]D. H. Jonassen and L. Rohrer-Murphy, "Activity theory as a framework for designing constructivist learning environments," Educational technology research and development, 1999, vol. 47, no. 1, pp. 61-79.

[186]A. Tolmie and J. Boyle, "Factors influencing the success of computer mediated communication (CMC) environments in university teaching: a review and case study," Computers \& Education, 2000, vol. 34, no. 2, pp. 119-140

[187]A. Jones and K. Issroff, "Learning technologies: Affective and social issues in computer-supported collaborative learning," Computers \& Education, 2005, vol. 44, no. 4, pp. 395-408.

[188]P. R. Pintrich, R. W. Marx, and R. A. "Boyle, beyond cold conceptual change: The role of motivational beliefs and classroom contextual factors in the process of conceptual change," Review of Educational Research, 1993, vol. 63, no. 2, pp. 167-199.

[189]M. Boekaerts, "Self-regulated learning: Where we are today," International Journal of Educational Research, 1999, vol. 31, no. 6, pp. 445-457.

[190]K. Hakkarainen, M. Bollström-Huttunen, R. Pyysalo, and K. Lonka, “Tutkiva oppiminen käytännössä: matkaopas opettajille," 2005.

[191]E. Lehtinen, "Tietoyhteiskunnan haasteet ja mahdollisuudet oppimiselle," Teoksessa E. Lehtinen (toim.), Verkkopedagogiikka. Helsinki: Edita, 1997, vol. 12, p. 40.

Copyright $\odot 2022$ by the authors. This is an open access article distributed under the Creative Commons Attribution License which permits unrestricted use, distribution, and reproduction in any medium, provided the original work is properly cited (CC BY 4.0).

Sarah A. L. Serhan is Ph.D candidate at the Faculty of Social Sciences \& Humanities, School of Education, Universiti Teknologi Malaysia, UTM, 81310, Skudai, Johor, Malaysia.

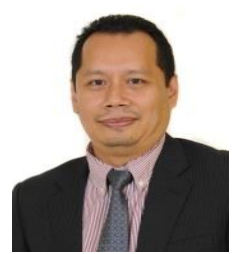

Noraffandy Yahaya is associate professor at the Faculty of Social Sciences \& Humanities, School of Education, Universiti Teknologi Malaysia, UTM, 81310, Skudai, Johor, Malaysia. 